\section{Alarms ring over bird flu mutations}

Scientists studying virus samples from the human outbreak of avian flu in Turkey have identified three mutations in the virus's sequence. They say that at least two of these look likely to make the virus better adapted to humans.

The Turkey outbreak is unusual, because of the large family clusters of cases; the fact that many of those infected have only mild symptoms; and the speed with which infections have arisen - twenty cases, including four deaths, in less than two weeks. So scientists are urgently trying to establish whether the virus is behaving differently in this outbreak from previous ones in Asia. In particular, international teams are investigating the possibility that the virus is moving between people.

${ }^{\alpha}$ With such a large number of cases within such a short period of time, human-to-human transmission is something that we've had to consider," says Maria Cheng, a spokeswoman at World Health Organization (WHO) headquarters in Geneva.

As Nature went to press, samples from the first two teenagers in the country to die had been sequenced by a WHO collaborating centre at the National Institute of Medical Research (NIMR) in London.

The results so far are not comforting. The first mutation found, announced last week, involves a substitution in one sample of an amino acid at position 223 of the haemoagglutinin receptor protein. This protein allows the flu virus to bind to the receptors on the surface of its host's cells.

This mutation has been observed twice before - in a father and son in Hong Kong in 2003 , and in one fatal case in Vietnam last year. It increases the virus's ability to bind to human receptors, and decreases its affinity for poultry receptors, making strains with this mutation better adapted to infecting humans.

The same sample also contained a mutation at position 153 of the haemoagglutinin protein, Nature has learned. Cheng says this information was not included in WHO statements, because ${ }^{\alpha i}$ is not clear what role this particular change plays".

Finally, both samples from the Turkish teenagers show a substitution of glutamic acid

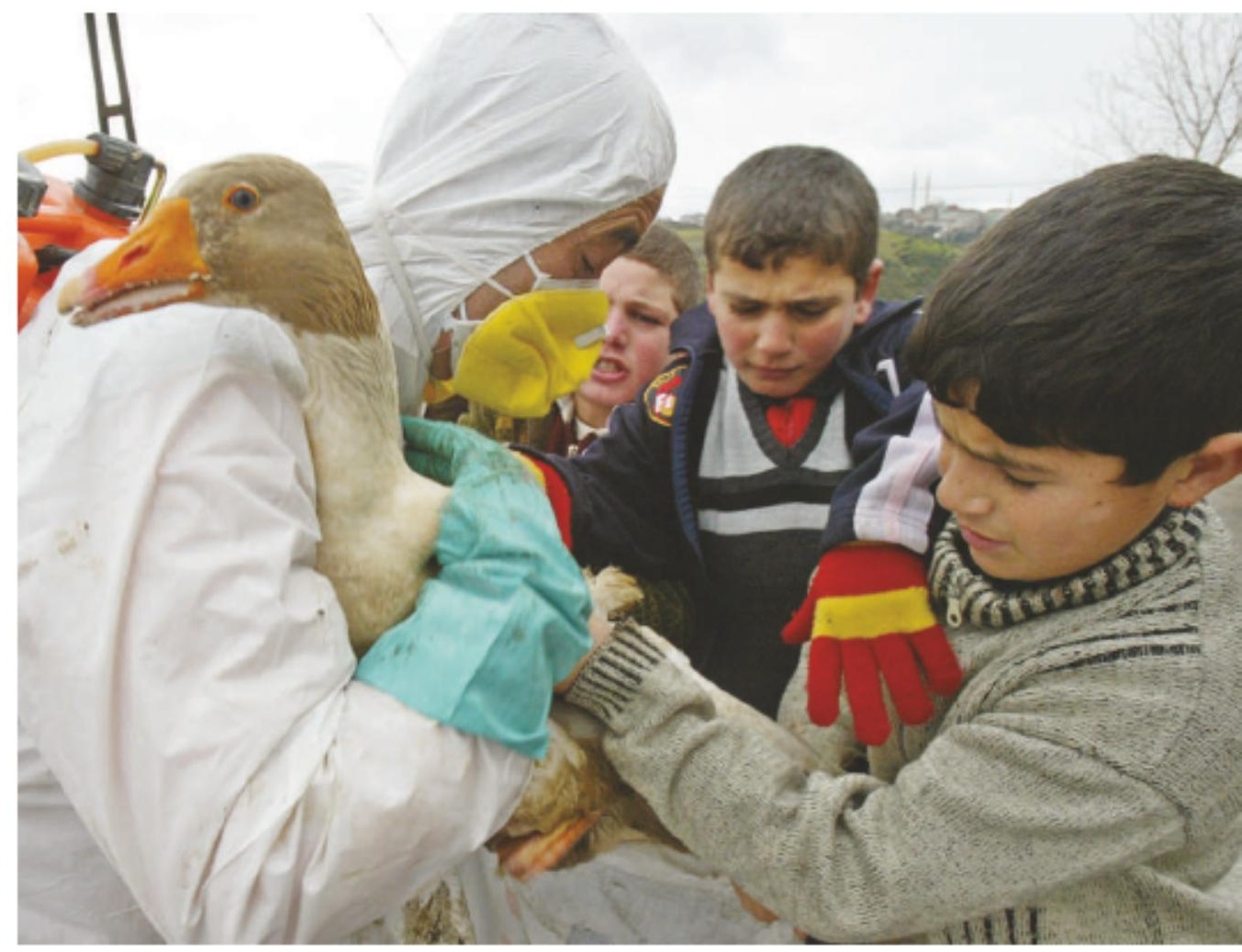

The recent outbreak of bird flu in Turkey has thrown up viruses with mutations that threaten humans.

with lycine, at position 627 of "Human-to-human the polymerase protein, which the virus uses to replicate its genetic material. This mutation has been seen in other flu sequences from Eurasian poultry over the past year. It was also present in the one person who died during an outbreak of H7N7 in the Netherlandsin 2003, and in a few

\section{transmission is}

something that we

have had to consider." people in Vietnam and Thailand.

The polymerase mutation is one of the ten genetic changes that gave rise to the 1918 pandemic flu virus. Like the 223 haemoagglutinin mutation, it signals adaptation to humans, says Alan Hay, director of a WHO influenza laboratory at the NIMR. "There is this glutamic acid-lysine

\title{
Doctor admits Lancet study is fiction
}

A Norwegian researcher dreamed up the lives and lifestyles of some 900 people and used them in a study on cancer. Then, last October, Jon Sudbø had his results published in The Lancet.

The revelation comes hard on the heels of the Woo Suk Hwang scandal, in which several important advances in human cloning reported by the South Korean researcher turned out to be faked.

The blatant nature of Sudbø's fiction emphasizes questions already being asked about the effectiveness of peer review, even in top journals, and about who should be responsible for catching fraud (see page 243).

The latest deception was discovered by

\section{Camilla Stoltenberg, a director of} epidemiology at the Norwegian Institute of Public Health in Oslo, who was catching up on her literature reading over Christmas. Sudbø's paper claims to analyse a publichealth database and show that taking anti-inflammatory drugs can reduce the incidence of mouth cancer (J. Sudbø et al. Lancet 366, 1359-1366; 2005). “I was surprised because it refers to the Cohort of Norway, for which I am responsible," Stoltenberg says. She knew that this could not have been the source of thelifestyle data as the paper claimed.

Last week, Sudbø, who is based at the Norwegian Radium Hospital in Oslo, 
flip," he explains. "Glutamic acid is associated with flu-virus replication in birds, and lycine is in primates."

The Turkey strains are the first in which the polymerase and receptor-binding mutations have been found together. They could make it easier for humans to catch the virus from poultry. But they might also favour human-tohuman transmission. This is because the polymerase change helps the virus to survive in the cooler nasal regions of the respiratory tract, and the haemoagglutinin mutation encourages the virus to target receptors in the nose and throat, rather than lower down in the lungs. The virus is thought to be more likely to spread through droplets coughed from the nose and throat than from infections lower down.

Hay points out, however, that it is difficult to predict how the mutations will actually influence the virus's behaviour. He adds that just two changes are unlikely to create efficient human-to-human transmission on their own.

Establishing what effects these changes are having on the epidemiology of the current outbreak is a top priority for research teams working in Turkey. "We must learn more about the mild cases and be absolutely sure of whether these viruses are behaving differently from those we have seen elsewhere," says Hay. "It is early days in terms of what we know about the viruses causing these infections."

Researchers are sequencing more strains from the Turkey cases, to see whether they share the mutations and to check for further changes. Samples were expected to arrive in London on 18 January, after being held up for more than a week in Turkey because of the Eid ul-Adha holiday period.

Declan Butler

\section{Will Germany choose a fair élite?}

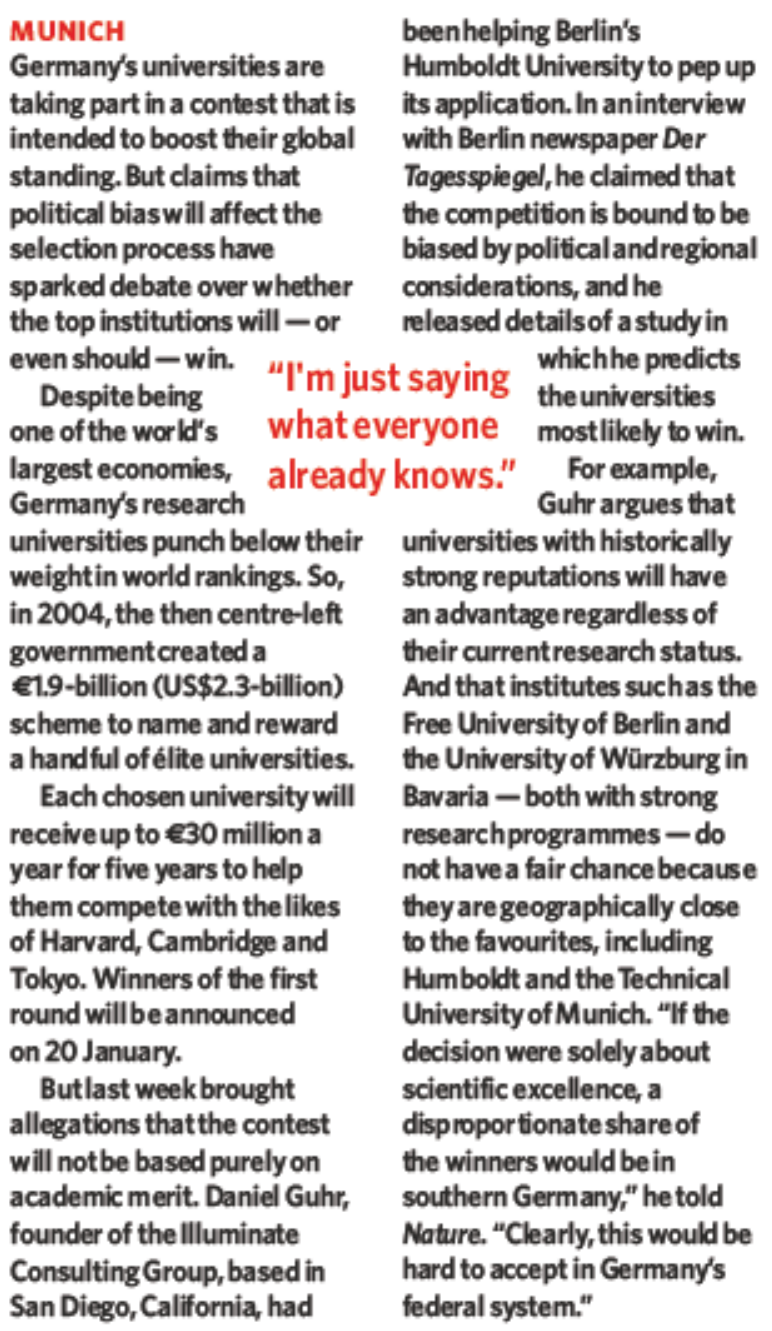

\section{MUNICH}

intended to boost their global

standing. But claims that

political biaswill affect the

selection process have

sparked debate over whethe

(tions will - or

Despite being

one of the world's

Germany's research

universities punch below their

governmentcreated a

1.9-billion (US\$2.3-billion)

handful of élite universities. receive up to 630 million a year for five years to help them compete with the likes on 20 January.

Butlast week brought allegations that the contest will not be based purely on academic merit. Daniel Guh Consulting Group, based in San Diego, California, had
Guhr adds that he sees such factors as "legitimate and reasonable" - withouta political component to the decision, even the strongest universities in the east, for example, the University of Dresden, would have little chance. But he says that biases should be properly acknowledged because of the consequences for the losers. "Funding and attention will focus on the new êlite."

The consultant has been almost unanimously criticized for his outburst. Humboldt cut ties with him, and research managers throughout Germany have rejected the idea. "The claims are totally unfounded," insists Eva-Maria Streier, s pokeswoman for Germany's main research agency, the DFG, which is running the competition. "Political interests will not play a role in the outcome."

Guhr says he is surprised by the response. "I'm just saying what everyone already knows," he says. Many will be keeping an eye on his predictions whenthe final results are announced. Robert Rentzsch

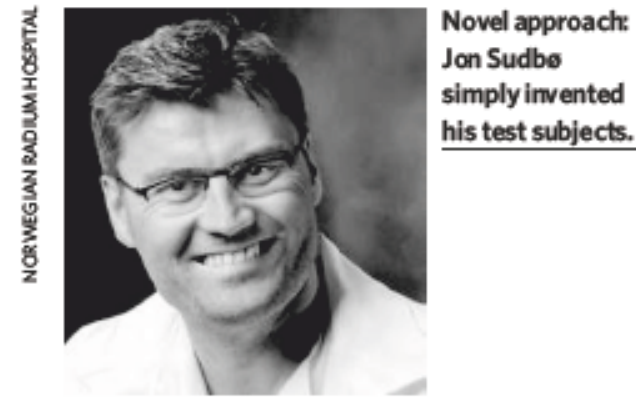

admitted that the data had not come from that database or any other, but from thin air.

Many details of this case still need to be worked out. There is some indication that Sudbø may have mental health problems. It is also not dear what his 13 co-authors knew about the fraud - the paper identifies three others as contributing equally to the research, and among the other co-authors areSudbø's wife and his identical twin. None of the authors could be reached for comment.

The hospital has asked that Sudbø's other work be examined in an independent investigation, to be set up this week by Anders Ekbom, an epidemiologist at the Karolinska Institute in Stockholm, Sweden. But the case is already set to change research policy in Norway. The country's health minister, Sylvia Brustad, announced on 16 January that previously stalled reforms on medical research will probably be law by the autumn. The new rules would put more responsibility for catching fraud on the shoulders of the institutions where the research was done.

Richard Horton, editor of The Lancet, insists his journal is not at fault. "This is all so similar to the Hwang thing that we have just been through," he says wearily. "Peer review is a great system for detecting badly done research, but if you have an investigator determined to fabricate an entire study, it is not possible to pickit up." The mechanism of peer review at his journal is currently being examined as part of the largest study ever conducted into the process (see page 252). Emma Marris 